\title{
METHEMALBUMIN. II. EFFECT OF PAMAQUINE AND QUININE ON PATHWAYS OF HEMOGLOBIN METABOLISM ${ }^{1,2}$
}

\author{
By WILLIAM D. BLAKE 8 \\ (From the Department of Medicine, New York University College of Medicine, and the \\ Research Service, Third [New York University] Medical Division, \\ Goldwater Memorial Hospital, New York City)
}

(Received for publication March 12, 1947)

\section{INTRODUCTION}

Methemalbuminemia has been described in association with massive intravascular hemolysis $(1,2,3,4)$ or with limited hemolysis in the presence of liver disease $(1,5)$. Similarly, the injection of large amounts of hemoglobin may result in methemalbuminemia (1), whereas smaller amounts do so only in the presence of a damaged liver (6). Hematin injected intravenously rapidly combines with serum albumin to form methemalbumin (7) which is then converted to bilirubin and is largely recoverable as fecal urobilinogen (8).

It has been noted that the concurrent administration of pamaquine and quinine also leads to methemalbuminemia, whereas neither drug alone produces this effect (9). The reproducibility of the phenomenon suggested the use of these drugs as a means of investigating methemalbumin metabolism. Studies were directed toward the relationship of methemalbuminemia to the degree and duration of hemolysis and hemoglobinemia, to the disappearance rate of methemalbumin as affected by drug action, and to the possible role of liver function.

\section{MATERIALS AND METHODS}

White patients with central nervous system syphilis were used as subjects. Some received therapeutic ma-

1 The work described in this paper was done under a contract, recommended by the Committee on Medical Research, between the Office of Scientific Research and Development and New York University.

2 The authors express their thanks to the Malaria Study Section of the National Institute of Health for editorial assistance and for arrangements in regard to the publication of this paper. They are also grateful to the Abbott Laboratories, E. I. du Pont de Nemours and Company, Inc., E. R. Squibb and Sons, Eli Lilly and Company, Sharp and Dohme, and Wyeth, Inc., for contributing toward the publication costs.

3 Captain, MC, AUS. laria during the study but the period immediately following malaria was avoided because of the questionable status of certain functions of the liver $(10,11,12)$. Serum bilirubin and bromsulfalein retention tests were normal, unless specifically mentioned.

Pamaquine naphthoate and quinine sulfate were administered orally, the dosage in each case being expressed in terms of the free base. Plasma pamaquine (13) and quinine concentrations (14) were estimated at intervals to ascertain reliability of drug intake. Pamaquine dosage regimens were either $15 \mathrm{mg}$. every four hours or $10 \mathrm{mg}$. every eight hours. Quinine was given as the sulfate in 0.6 gram doses every eight hours.

Commercial hemin * was recrystallized (15) prior to being prepared for intravenous injection (8). One of five patients receiving hematin suffered dizziness and abdominal and back pain of short duration. The injection was discontinued and the patient withdrawn from the study. Uncomplicated thrombophlebitis was encountered following some of the slower injections. No other untoward effects were noted.

Hemoglobin solution 5 for intravenous injection was received and stored in $500 \mathrm{cc}$. sterile flasks at a concentration of $7.5 \pm 0.5$ grams per cent. More than 98 per cent was present as oxyhemoglobin. One of the four patients receiving hemoglobin intravenously experienced abdominal cramps, nausea and vomiting and another, transient back pain. No hyperpyrexia or other untoward effects were encountered.

The estimation of methemalbumin concentration has been described in full in the preceding paper (9). Hemoglobin was estimated by the method of Evelyn (16). Serum hemoglobin was estimated on the Beckman photoelectric spectrophotometer by a method similar to the one used for methemalbumin, except that optical densities were recorded at $415 \mathrm{~m} \mu$ wave-length, the absorption maximum of oxyhemoglobin. At this wave-length, after the correction blank had been subtracted, an optical density of $0.076(1 \mathrm{~cm}$. cell) was estimated as equivalent to a hemoglobin concentration of $1.0 \mathrm{mg}$. per cent.

Serum bilirubin was estimated by the method of Malloy and Evelyn (17), fecal urobilinogen by a modification of Watson's method (18) yielding 90-100 per cent recovery, coproporphyrin by the method of Dobriner and Rhoads (19), and bromsulfalein retention in per cent

\footnotetext{
4 Eastman Kodak Company.

- Supplied through the courtesy of Dr. Robert B. Pennell of Sharp \& Dohme, Inc.
} 
by the estimation of serum bromsulfalein at five and 30 minutes after the intravenous injection of $5 \mathrm{mg}$. per kilo of body weight.

\section{RESULTS}

Hemolysis during combined pamaquine-quinine administration. Fecal urobilinogen excretion was estimated in two individuals during successive

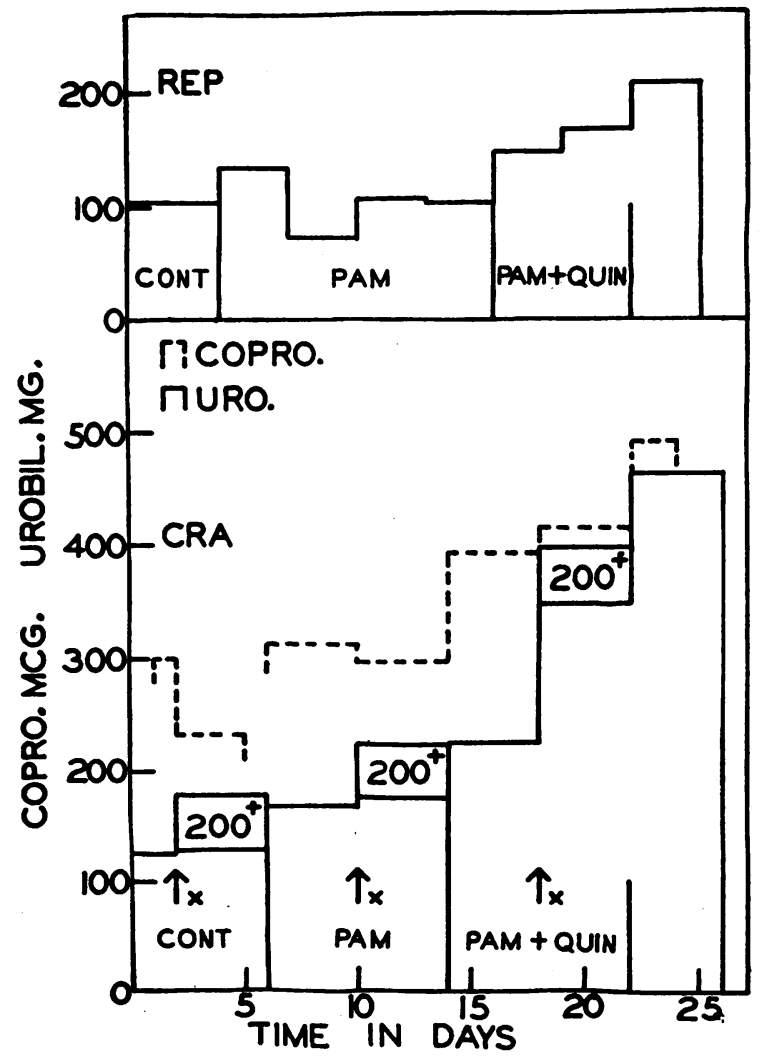

Fig. 1. Fecal Urobilinogen and Total CoproporPHyRIN ExcRetion as AfFected by the Administration of Pamaquine and Combined Pamaquine and QUININE

The excretion per 24 hours of the two pigments was estimated during a control period (CONT), during the administration of $90 \mathrm{mg}$. of pamaquine base daily (PAM), and during the administration of $90 \mathrm{mg}$. of pamaquine base and $1.8 \mathrm{gm}$. quinine base daily (PAM + QUIN). 48-96 hour stool specimens were pooled as indicated in the figure.

The excretion on patient Cra was complicated by the intravenous administration of $400 \mathrm{mg}$. of hematin, as indicated by the arrows on the lower part of the figure. The four-day period following each hematin injection includes a blocked off area which represents the urobilinogen excretion from 50 per cent of the injected hematin on the assumption that a minimum of 50 per cent is recoverable as fecal urobilinogen (8). control, pamaquine, and combined pamaquine-quinine periods (Figure 1). Pamaquine dosage was $90 \mathrm{mg}$. per day throughout in both patients. Only during combined drug administration was urobilinogen output significantly increased over the control period. A slightly increased output of doubtful significance occurred during pamaquine alone in one patient. Total coproporphyrin excretion, estimated in one of the patients, also showed an increased output only during combined pamaquine-quinine administration (Figure 1). The administration of $400 \mathrm{mg}$. of hematin had no effect on coproporphyrin output in this individual.

Methemalbuminemia not a result of hemolysis alone. One of the patients mentioned above developed methemalbuminemia on the third day of combined drug administration. It was estimated from the increment in fecal urobilinogen excretion that no more than 2.5 grams of hemoglobin was catabolized per day in excess of the patient's control rate. A comparable amount of hemoglobin was administered intravenously to five patients who were receiving no drug to determine whether an equivalent degree of hemolysis alone would produce methemalbumin. Two patients received, respectively, single doses of 7.0 and 9.0 grams of hemoglobin in one hour (Table I) and three received multiple small injections of $4.5-6.5$ grams per day in divided doses for periods of two to four days (Figure 2). None developed methemalbuminemia. One of the latter patients subsequently was given a large single dose of 15.0 grams of hemoglobin. Methemalbumin was present in the serum of this patient at 24 hours, at which time no free hemoglobin was demonstrable (Table I).

Methemalbuminemia following hemoglobin injection during pamaquine and/or quinine administration. Two patients were given intravenously $4.5-6.5$ grams of hemoglobin a day in divided doses for three days during pamaquine and for three days during quinine administration (Figure 2), to ascertain whether either drug alone would promote methemalbumin formation if free hemoglobin were available. No significant methemalbumin appeared in one patient during the pamaquine period, whereas in the other, there was trace formation. Quinine caused clear-cut methemalbumin formation under the same conditions of hemoglobin administration. 
TABLE I

Serum optical density at 405 and 415 mu wave-lengths (the absorption maxima of methemalbumin and hemoglobin respectively) 24 hours after a single intravenous dose of hemoglobin

Hemolysis resulting from the handling of the blood or hemoglobinemia is judged qualitatively by the shape of the absorption curve from $540 \mathrm{~m} \mu$ to $600 \mathrm{~m} \mu$ wave-length.

\begin{tabular}{|c|c|c|c|c|c|c|c|c|c|c|}
\hline \multirow{2}{*}{ Patient } & \multirow{2}{*}{$\begin{array}{c}\text { Hemo- } \\
\text { globin } \\
\text { dose }\end{array}$} & \multirow{2}{*}{$\underset{\text { berum }}{\text { Silirubin }}$} & \multicolumn{3}{|c|}{ Optical density $405 \mathrm{~m} \mu$} & \multicolumn{3}{|c|}{ Optical density $415 \mathrm{m \mu}$} & \multirow{2}{*}{ Hemolysis } & \multirow{2}{*}{$\begin{array}{l}\text { Methem- } \\
\text { albumin }\end{array}$} \\
\hline & & & Actual & Expected & Difference & Actual & Expected & Difference & & \\
\hline $\begin{array}{c}\text { ROF } \\
\text { KEN } \\
\text { BRA } \\
\text { BRA } \\
\text { (at } 48 \text { hours) }\end{array}$ & $\begin{array}{c}\text { grams } \\
7.0 \\
9.0 \\
15.0\end{array}$ & $\begin{array}{l}m g . \% \\
.42 \\
.45 \\
.47 \\
.40\end{array}$ & $\begin{array}{r}.564 \\
.669 \\
1.860 \\
.905\end{array}$ & $\begin{array}{l}.565 \\
.580 \\
.590 \\
.550\end{array}$ & $\begin{array}{r}-.001 \\
+\quad .089 \\
+1.270 \\
+\quad .355\end{array}$ & $\begin{array}{r}.619 \\
.707 \\
1.683 \\
.895\end{array}$ & $\begin{array}{l}.595 \\
.615 \\
.630 \\
.585\end{array}$ & $\begin{array}{l}+.024 \\
+.092 \\
+1.053 \\
+\quad .310\end{array}$ & $\begin{array}{c}0 \\
+ \\
0 \\
\text { trace }\end{array}$ & $\begin{array}{c}0 \\
0 \\
+++ \\
++\end{array}$ \\
\hline
\end{tabular}

Two patients received a similar series of hemoglobin injections during combined pamaquinequinine therapy (Figure 2). Additional methemalbumin was formed from the hemoglobin in-

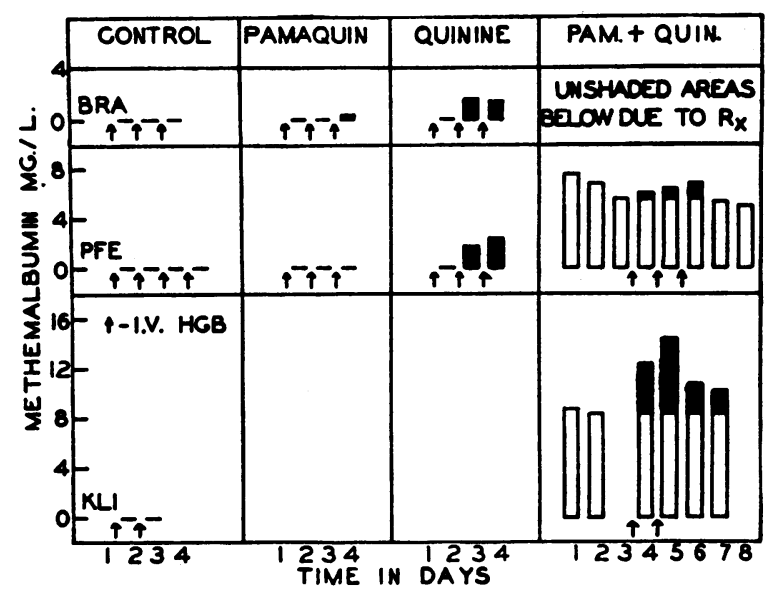

Fig. 2. Methemalbuminemia as Observed during the Intravenous Administration of Multiple Small Doses of HEMOGLOBIN

Hemoglobin was administered in daily dosage of 4.8 grams (BRA), 5.0 grams (PFE), or 6.5 grams (KLI) on successive days as indicated by the arrows in the figure and was given during control periods and during the administration of $90 \mathrm{mg}$. pamaquine base daily and/or 1.8 grams quinine base daily. Rest periods of at least four days were allowed between each course of drug administration. The dosage of pamaquine during combined drug administration was lowered in patients PFE and KLI from 90 to $30 \mathrm{mg}$. daily after four days at the higher dose. This was done in order to obtain a stable or falling methemalbumin level prior to hemoglobin injection. The unshaded areas during combined drug administration represent methemalbumin attributable to therapy alone; the shaded areas, that resulting from hemoglobin injection. Such a division is at best an approximation. jected and was superimposed upon pre-existing methemalbuminemia present as the result of pamaquine-quinine administration. The amount of additional methemalbumin derived from the intravenously injected hemoglobin was of the same order of magnitude as that derived from hemoglobin during the administration of quinine alone.

Disappearance rate of serum hemoglobin related to combined pamaquine-quinine administration. The above observations suggest that quinine

\section{TABLE II}

Disappearance rate of hemoglobin injected intravenously over $a$ period of one hour during control and combined pamaquine-quinine administration periods

Patient ROF received 7.0 grams of hemoglobin on both occasions, patient KEN 9.0 grams on both occasions. Pamaquine dosage was $15 \mathrm{mg}$. every six hours and quinine dosage $\mathbf{0 . 3}$ grams every six hours for both patients.

\begin{tabular}{|c|c|c|c|c|c|c|}
\hline \multirow{3}{*}{$\underset{\text { (hours) }}{\text { Time }}$} & \multirow{2}{*}{\multicolumn{2}{|c|}{$\begin{array}{l}\text { Serum hemoglobin } \\
\text { concentration } \\
\text { (mg. per cent) }\end{array}$}} & \multicolumn{4}{|c|}{ Diminution per hour } \\
\hline & & & \multicolumn{2}{|c|}{$\begin{array}{c}\text { Concentration } \\
\text { (mg.per cent })\end{array}$} & \multicolumn{2}{|c|}{ Per cent } \\
\hline & $\begin{array}{c}\text { Control } \\
\text { period }\end{array}$ & $\begin{array}{c}\text { Drug } \\
\text { period }\end{array}$ & $\begin{array}{c}\text { Control } \\
\text { period }\end{array}$ & $\begin{array}{c}\text { Drug } \\
\text { period }\end{array}$ & $\begin{array}{c}\text { Control } \\
\text { period }\end{array}$ & $\underset{\text { period }}{\text { Drug }}$ \\
\hline
\end{tabular}

\section{Patient ROF}

\begin{tabular}{r|r|r|r|r|r|r}
\hline 2 & 197 & 268 & & & & \\
4 & 107 & $111^{*}$ & 45 & 79 & 23 & 30 \\
7 & 26 & $18^{*}$ & 27 & 31 & 25 & 28 \\
& & & & & & \\
\hline
\end{tabular}

Patient KEN

\begin{tabular}{r|r|r|r|r|r|r}
\hline 2 & 240 & 245 & & & & \\
4 & 108 & $103^{*}$ & 66 & 71 & 28 & 29 \\
7 & 19 & $21^{*}$ & 30 & 27 & 28 & 26 \\
& & & & & & \\
\hline
\end{tabular}

* Methemalbumin formation makes these values somewhat inaccurate, more particularly at the seven-hour period, 
and combined pamaquine-quinine interfere in some way with the metabolism of injected hemoglobin and so promote methemalbumin formation. For this reason, the disappearance rate of hemoglobin from serum was estimated in two patients during control and combined drug regimen periods (Table II). Combined pamaquine-quinine caused no demonstrable alteration in the disappearance rate of injected hemoglobin. The methods used for the estimation of serum hemoglobin concentration are subject to some error during combined drug at the four-hour and, more particularly, at the seven-hour periods due to the appearance of methemoglobin and methemalbumin. However, it was determinable that no marked acceleration or retardation of hemoglobin removal occurred.

Methemalbumin disappearance rate as affected by drug administration. On the assumption that one of the drug regimens might interfere with methemalbumin degradation and thereby lead to its accumulation in the serum, methemalbumin disappearance rates were estimated in four patients. $400 \mathrm{mg}$. of hematin were injected intravenously prior to each determination in order to achieve a high initial level of methemalbumin. Three in-

\section{TABLE - III}

Change in serum methemalbumin concentration (expressed in mg./L as hemin) following the intravenous injection of hematin, as influenced by drug administration

Pamaquine dosage was $15 \mathrm{mg}$. of the base every four hours and quinine dosage was 0.6 gram of the base every eight hours.

\begin{tabular}{l|c|c|c|c|c}
\hline \hline \multicolumn{6}{|c}{$\begin{array}{c}\text { Diminution in methemalbumin concentration } \\
\text { per hour (mg./L as hemin) }\end{array}$} \\
\hline \multicolumn{6}{|c}{ Interval } \\
\hline $\begin{array}{c}1-4 \\
\text { hours }\end{array}$ & $\begin{array}{c}4-12 \\
\text { hours }\end{array}$ & $\begin{array}{c}12-24 \\
\text { hours }\end{array}$ & $\begin{array}{c}24-48 \\
\text { hours }\end{array}$ & $\begin{array}{c}48-72 \\
\text { hours }\end{array}$ \\
\hline
\end{tabular}

Patient CRA

\begin{tabular}{l|l|l|l|l|l}
\hline Control & 5.7 & 3.6 & 1.6 & 0.75 & 0.27 \\
Pamaquine & 4.1 & 3.4 & 1.8 & 0.72 & 0.39 \\
$\begin{array}{c}\text { Pamaquine- } \\
\text { quinine* }\end{array}$ & 3.9 & 3.3 & 1.5 & 0.87 & 0.31 \\
\hline
\end{tabular}

Per cent diminution per hour

\begin{tabular}{l|l|l|l|l|l}
\hline Control & 6.4 & 5.0 & 3.4 & 2.7 & 2.7 \\
Pamaquine & 4.2 & 4.0 & 3.2 & 2.1 & 2.1 \\
$\begin{array}{c}\text { Pamaquine- } \\
\text { quinine* }\end{array}$ & 4.3 & 4.2 & 2.8 & 2.4 & 2.1 \\
\hline
\end{tabular}

* See footnote 6 .
TABLE IV

The disappearance rate of serum methemalbumin following the intravenous injection of $400 \mathrm{mg}$. of hematin as influenced by drug administration

Pamaquine and quinine dosages were the same as those listed in Table III. The probability figures indicate that the slopes obtained during drug administration are significantly different from the control on the same individual.

\begin{tabular}{|c|c|c|c|c|c|c|c|}
\hline \multirow{2}{*}{$\begin{array}{c}\mathrm{Pa}- \\
\text { tient }\end{array}$} & \multirow{2}{*}{ Regimen } & \multicolumn{3}{|c|}{$\begin{array}{c}\text { Methemalbumin } \\
\text { concentration } \\
(m g . / L)\end{array}$} & \multirow{2}{*}{$\begin{array}{c}\text { Aver- } \\
\text { age } \\
\text { dimi- } \\
\text { nution } \\
\text { per 24 } \\
\text { hours } \\
\text { (per } \\
\text { cent) }\end{array}$} & \multirow{2}{*}{ Slope } & \multirow{2}{*}{$\begin{array}{l}\text { Proba- } \\
\text { bility }\end{array}$} \\
\hline & & $\begin{array}{c}24 \\
\text { hours }\end{array}$ & $\begin{array}{c}48 \\
\text { hours }\end{array}$ & $\mid \begin{array}{c}72 \\
\text { hours }\end{array}$ & & & \\
\hline CRA & $\begin{array}{l}\text { Control } \\
\text { Pamaquine } \\
\text { Pamaquine- } \\
\text { quinine* }\end{array}$ & $\begin{array}{l}27.9 \\
35.4 \\
37.2\end{array}$ & $\begin{array}{l}9.94 \\
18.0 \\
16.6\end{array}$ & $\begin{array}{l}3.61 \\
9.11 \\
8.44\end{array}$ & $\begin{array}{l}64.1 \\
49.3 \\
\\
52.3\end{array}$ & $\begin{array}{l}-.444 \\
-.302 \\
-.332\end{array}$ & $\begin{array}{l}<.01 \\
<.02\end{array}$ \\
\hline WIT & $\begin{array}{l}\text { Control } \\
\text { Pamaquine- } \\
\text { quinine* }\end{array}$ & $\begin{array}{l}31.7 \\
21.7\end{array}$ & $\begin{array}{l}7.77 \\
7.65\end{array}$ & $\begin{array}{l}2.97 \\
3.02\end{array}$ & $\begin{array}{l}72.7 \\
62.7\end{array}$ & $\begin{array}{l}-.586 \\
-.428\end{array}$ & $<.01$ \\
\hline REP & $\begin{array}{l}\text { Control } \\
\text { Pamaquine }\end{array}$ & $\begin{array}{l}27.3 \\
25.9\end{array}$ & $\begin{array}{r}6.94 \\
8.59\end{array}$ & $\begin{array}{l}1.64 \\
2.73\end{array}$ & $\begin{array}{l}75.5 \\
67.5\end{array}$ & $\begin{array}{l}-.611 \\
-.488\end{array}$ & $<.02$ \\
\hline MAS & $\begin{array}{l}\text { Control } \\
\text { Control }\end{array}$ & $\begin{array}{l}42.7 \\
39.9\end{array}$ & $\begin{array}{l}20.0 \\
18.6\end{array}$ & $\begin{array}{l}7.62 \\
9.03\end{array}$ & $\begin{array}{l}57.6 \\
52.9\end{array}$ & $\begin{array}{l}-.374 \\
-.322\end{array}$ & $>.18$ \\
\hline
\end{tabular}

* See footnote 6 .

jections were given eight days apart to the first patient: The first was given during the control period, the second during pamaquine administration, and the third, during combined pamaquinequinine administration. The concentration of methemalbumin was estimated at intervals and the per cent diminution per hour calculated for specified periods (Table III). The rate of disappearance under all conditions diminished during the first 24 hours, after which it remained essentially constant. ${ }^{B}$ Pamaquine and combined pamaquine-quinine appear to have lowered the disappearance rate. This effect is more apparent during the first 12 hours, but the order of magnitude is sufficiently low to be of uncertain significance. Comparison of the disappearance rates in all patients was made on the basis of the methemalbumin concentrations estimated at 24,48 , and 72 hours (Table IV). The calculated average rates of methemalbumin removal during pamaquine and during combined drug administration were

\footnotetext{
6 To calculate the disappearance rates during combined pamaquine-quinine administration, the methemalbumin already present as a result of drug therapy was subtracted from the total value obtained. This correction is admittedly only an approximation.
} 
each about 11 per cent lower than during the control periods. Apparently quinine, when combined with pamaquine, did not augment the retardation due to pamaquine alone.

The data on serum bilirubin formation and disappearance following the intravenous administration of hemoglobin and hematin during pamaquine suggest some similarity to liver disease. The serum bilirubin concentration curves during pamaquine or combined pamaquine-quinine in these situations were more elevated than during the control period on the same individual (Figure 3).

\section{DISCUSSION}

The methemalbuminemia which is observed during the concurrent administration of pamaquine and quinine appears to be the result of two phenomena, viz., an increase in the catabolism of hemoglobin and an interference in its subsequent degradation. The experimental data indicate that the first of these two phenomena results from the synergistic action of pamaquine and quinine, whereas the second may be due to the action of quinine alone. This viewpoint is justified by the following observations. Increased hemoglobin catabolism as evidenced by increased fecal urobilinogen excretion is apparent during combined drug administration but not when either drug is administered in the same dosage alone. When moderate hemolysis is simulated by small intravenous doses of hemoglobin, no measurable methemalbumin is formed. During quinine administration, such simulated hemolysis does lead to the definite formation of serum methemalbumin. Such methemalbumin formation is of the same order of magnitude as when similar injections of hemoglobin are given to patients on a combined drug regimen.

During the administration of pamaquine alone, simulated hemolysis may lead to trace formation of methemalbumin and, when added to quinine, pamaquine may slighly increase the methemalbuminemia resulting from the intravenous injections of hemoglobin. This effect of pamaquine is presumably due to a retardation of the removal of

\footnotetext{
It has been assumed that quinine alone in the doses given does not elevate fecal urobilinogen excretion. Unpublished data on one patient are consistent with this assumption.
}

serum methemalbumin rather than an increase in its formation, as is the case with quinine. This assumption seems justified by the data which indicate that pamaquine retards methemalbumin disappearance by about 11 per cent per day, an effect not augmented by quinine.

Further observations on the action of quinine and pamaquine are less conclusive. Combined pamaquine-quinine does not significantly alter the disappearance rate of injected hemoglobin. This observation excludes retention of serum hemoglobin as the cause of methemalbumin formation. It does not exclude the possibility that an increased percentage of the hemoglobin that breaks

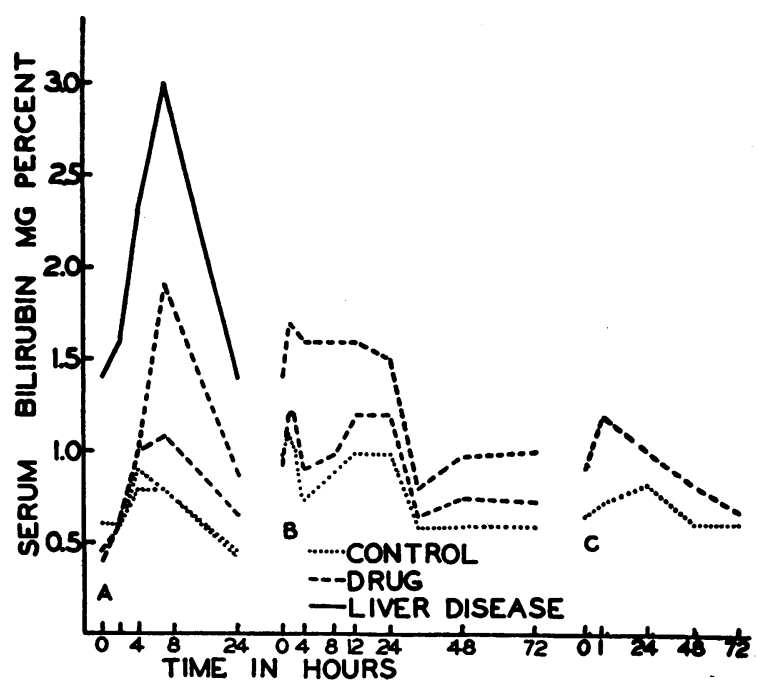

Fig. 3. Serum Bilirubin Concentration Curve Following the INTRAVENous Injection of Hemoglobin or Hematin as Influenced by Drug Administration or Liver Disease

(A) Two patients received hemoglobin intravenously, one 7.0 grams, the other, 9.0 grams, during a control period (dotted line) and during combined pamaquinequinine administration (dashed line). One patient with well documented cirrhosis of the liver received 11.7 grams of hemoglobin (solid line).

(B) Patient CRA received $400 \mathrm{mg}$. hematin intravenously during a control period (dotted line), during pamaquine administration (lower dashed line), and during combined pamaquine-quinine administration (upper dashed line).

(C) Patient REP received $400 \mathrm{mg}$. hematin during a control period (dotted line) and during pamaquine administration (dashed line).

Pamaquine dosage was $60 \mathrm{mg}$. base daily for the patients in (A), $90 \mathrm{mg}$. base daily for those in (B) and $(\mathrm{C})$. 
down is converted to hematin rather than some other pigment.

Patients receiving combined pamaquine-quinine for a week or more develop significant hyperbilirubinemia (9). This is most likely a reflection of impaired liver function in the presence of added hemoglobin destruction since greater increases in fecal urobilinogen than those found, occur without significant hyperbilirubinemia (20). In addition, pamaquine causes abnormal elevation of serum bilirubin concentration following the intravenous injection of large doses of hemoglobin or hematin. It is also probable that pamaquine may retard the removal of methemalbumin from serum indirectly by impairing some functional capacity of the liver. Similarly, one may speculate that liver disease causes some degree of methemalbumin retention.

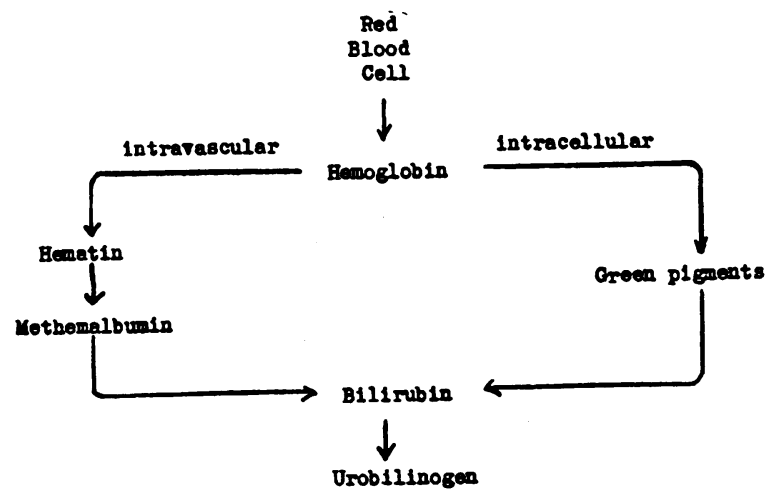

Fig. 4. A Diagrammatic Representation of the Metabolism of Hemoglobin Liberated IntravascuLARLY

The formation of the green pigments presumably takes place in the reticulo-endothelial system.

Normally, hemoglobin catabolism is an intracellular process and presumably little or no serum methemalbumin is formed (21). Figure 4 is a diagrammatic representation of one metabolic scheme of intravascular hemoglobin breakdown, including methemalbumin in its probable relation to the other pigments under discussion. When, as in hemolytic diseases, hemoglobin is liberated into the bloodstream, it may be degraded to hematin as well as to the green pigments. Duesberg (21) considered small amounts of injected hemoglobin to be almost exclusively converted to bilirubin by the normal pathway, methemalbumin occurring only under abnormal conditions. Ross $(3,4)$ has concluded that methemalbuminemia following massive intravascular hemolysis is a reflection of the retention of serum hemoglobin due to saturation of the normal paths of hemoglobin removal.

Conversely, Fairley (1) has suggested that regardless of the degree of hemolysis some of the intravascular hemoglobin is converted to methemalbumin. He observed that the intravenous injection of large amounts of hemoglobin, 14 grams or more, produced measurable methemalbumin formation, an effect not produced by smaller amounts. This has been confirmed in the present study (Table I), the methemalbuminemia 24 hours after 15 grams of intravenous hemoglobin resulting without associated hemoglobin retention. The disappearance of methemalbumin appears to be slower than normal during pamaquine administration and is probably also slowed by liver disease (see previous discussion). In both conditions methemalbumin may be observed in the serum following the injection of hemoglobin otherwise too small in quantity to cause measurable methemalbumin formation (6). These observations lend support to the hypothesis that even small amounts of intravascular hemoglobin normally break down to form methemalbumin, which becomes apparent only if its removal from the serum is retarded. For these reasons methemalbuminemia is believed to be a reflection primarily of the quantity of free hemoglobin in serum rather than the retention thereof.

The fate of methemalbumin has been well established by Pass, Schwartz and Watson (8) who demonstrated that injected hematin is quantitatively converted to bilirubin. Consistent with this are the observations made in one patient on two occasions. Following the intravenous injection of hematin fecal urobilinogen excretion is increased and total coproporphyrin excretion is not appreciably changed.

\section{SUMMARY AND CONCLUSIONS}

The drugs pamaquine and quinine act synergistically to cause increased hemoglobin catabolism. An amount of hemoglobin equivalent to the excess catabolized by combined pamaquinequinine, injected intravenously, does not result in measurable methemalbumin formation in normal individuals. 
During quinine and, to a much lesser extent, during pamaquine administration, the intravenous injection of hemoglobin does result in methemalbuminemia. Quinine acts independently in some way to increase the amount of intravascular hemoglobin degraded to hematin. Pamaquine acts independently to retard slightly conversion of methemalbumin to bilirubin, possibly indirectly, by impairing some functional capacity of the liver. In this manner, pamaquine is believed to cause methemalbumin to accumulate to a measurable quantity during intravenous hemoglobin administration.

Methemalbumin is considered a normal intermediary in hemoglobin metabolism whenever free hemoglobin is present in the serum. Methemalbuminemia becomes apparent only when hemolysis or simulated hemolysis releases a large quantity of hemoglobin into the plasma (i.e., about 10-15 grams), or with lesser amounts when the conversion of methemalbumin to bilirubin is retarded, allowing the former to accumulate in the serum.

\section{BIBLIOGRAPHY}

1. Fairley, N. H., Methaemalbumin. I. Clinical aspects. Quart. J. Med. (New Series), 1941, 10, 95.

2. Fox, C. L., Jr., and Ottenberg, R., Acute hemolytic anemia from the sulfonamides. J. Clin. Invest., 1941, 20, 593.

3. Ross, J. F., Hemoglobinemia and the hemoglobinurias, a review. New England J. Med., 1945, 233, 691.

4. Ross, J. F., and Paegel, B. L., Acute hemolytic anemia and hemoglobinuria following sulfadiazine medication. Blood, 1946, 1, 189.

5. Schumm, O., Hämatin als pathologischer Bestandteil des Blutes. Ztschr. f. physiol. Chem., 1916, 97, 32.

6. Duesberg, R., and Hagenbeck, H., Die Hämaglobinbelastung als Leberfunkionsprufung. Deutsches Arch. f. klin. Med., 1938, 182, 22.

7. Fairley, N. H., Methaemalbumin. II. Synthesis, chemical behavior and experimental production. Quart. J. Med. (New Series), 1941, 10, 115.
8. Pass, I. J., Schwartz, S., and Watson, C. J., The conversion of hematin to bilirubin following intravenous administration in human subjects. J. Clin. Invest., 1945, 24, 283.

9. Rosenfeld, M., Zubrod, C. G., Blake, W. D., and Shannon, J. A., Methemalbumin. I. Appearance during administration of pamaquine and quinine. J. Clin. Invest., 1948, 27, Suppl., 138.

10. Guttman, S. A., Patter, H. R., Hanger, F. M., Moore, D. B., Pierson, P. S., and Moore, D. H., Significance of cephalin-cholesterol flocculation test in malarial fever. J. Clin. Invest., 1945, 24, 296.

11. Kopp, I., and Solomon, H. C., Liver function in therapeutic malaria. Am. J. Med. Sci., 1945, 205, 90.

12. Mirsky, I. A., von Brecht, R., and Williams, L. D., Hepatic disfunction in malaria. Science, 1944, 99, 20.

13. Brodie, B. B., Udenfriend, S., and Taggart, J. V., The estimation of basic organic compounds in biological material. IV. Estimation by coupling with diazonium salts. J. Biol. Chem., 1947, 168, 327.

14. Brodie, B. B., Udenfriend, S., Dill, W., and Downing, G., The estimation of basic organic compounds in biological material. II. Estimation of fluorescent compounds. J. Biol. Chem., 1947, 168, 311.

15. Fischer, H., Recrystallization of hemin. Organic Syntheses, 1941, 21, 53.

16. Evelyn, K. A., The determination of oxyhemoglobin with the photoelectric colorimeter. J. Biol. Chem., 1936, 115, 63.

17. Malloy, H. T., and Evelyn, K. A., The determination of bilirubin with the photoelectric colorimeter. J. Biol. Chem., 1937, 119, 481.

18. Schwartz, S., Sborov, V., and Watson, C. J., The determination of urobilinogen on the photoelectric colorimeter. Am. J. Clin. Path., 1944, 14, 598.

19. Dobriner, K., and Rhoads, C. P., Quantitative determination of urinary coproporphyrin. New England J. Med., 1938, 219, 1027.

20. Miller, E. B., Singer, K., and Dameshek, W., Use of the daily fecal output of urobilinogen and the hemolytic index in the measurement of hemolysis. Arch. Int. Med., 1942, 70, 722.

21. Duesberg, R., Uber die biologischen Beziehungen des Hämoglobins zu Bilirubin und Hämatin bei normalen und pathologischen Zuständen des Menschen. Arch. exper. Path. u. Pharmakol., 1934, 174, 305. 